\title{
The Challenges of the "Husband Wife" Phenomenon in Family and Marital Unequal Relationships
}

\author{
C. Noah Musa, Ph.D. \\ Department of Educational Studies and Management \\ Faculty of Education, University of Benin, Benin City \\ Email: readurbook50@gmail.com
}

\section{Doi:10.5901/jesr.2014.v4n3p297}

\begin{abstract}
This paper addresses the phenomenon of husband wife in a marriage. It describes the husband wife experience as one in which a wife plays the role of the husband in a role-reversal situation. It examines the socio-psychological challenges which the husband wife experience poses to the institution of marriage, pointing out that the situation simply reduces the male partner in the marriage to a househusband. While identifying the conditions which could engender the husband wife situation such as job loss, sickness or lack of education, the paper recommends that marriages should be contracted on the foundation of strong moral principles which engender moral respect for both partners in the marriage.
\end{abstract}

Keywords: Husband wife, househusband, conjugal role, symmetrical family, domesticity, stereotype, husband abuse

\section{Introduction}

Recent changes in society have been so global that the effects have been very telling even on the smallest units of societies. One of such units is the family where phenomenal changes have been taking place to the point of challenging the conventional concept of the family. Marriage, the central institutional component of the family has been seriously threatened. Additionally, the current alarming rate of divorce has given rise to the argument that the institution of marriage is becoming less popular in many societies. It is even argued that many people, especially in the advanced economies, are developing several alternatives to the conventional concept of married life. In recent times, the incidence of single motherhood has been on the rise. So also is the practice of co-habitation, surrogacy and very recently - the unconventional concept of "same sex marriage". It was Chester (1985) who observed that marriage rates among young adults have drastically declined in the west, pointing out that Sweden and Denmark began to have falling marriage rates especially among the under 30s. Britain joined the trend and was quickly followed by the United States of America, Germany and finally France. He indicated that in 1981, marriage among teenage women fell from one in eleven in 1971 to as much as one in twenty four.

Many of the alternative relationships which have been invented to challenge marriage have generally been based on the notion of men being the main beneficiaries of the institution of marriage. Delphy (1984) \& Secombe (1975) all argue that housewives perform domestic functions essentially for the benefit of their husbands. According to Delphy, women are exploited, by working only for the subsistence provided by their husbands. She considers husbands as part of the patriarchal proletariat who exploit the womenfolk. As a way out, she suggested that women should form a vanguard independently to overthrow patriarchy and challenge the existing family relationships which subordinate them to exploitation by men. This is why one of the truisms for women's movement is "that the home is a prison for women, trapping them in housework and childcare, frustrating them and distorting their need for fulfillment as whole persons" (Roache, 1991). It is in the context of the above radically provocative concepts that this paper is conceived as an attempt to critically examine the ramifications of the family and family relationships in terms of the role of the main partners in the institution of marriage. Of particular concern is the emerging threatening phenomenon of role reversal in which the husband assumes the traditional role of the wife while the wife assumes the role of the husband hence the concept "husband wife". Both husband and wife function within the family. So, what is a family?

\section{The Family}

The family is a social group which is characterized by common residence, economic cooperation and reproduction. It 
generally includes adults of both sexes, at least two of whom maintain a socially approved sexual relationship (marriage), and one or more children and some members of the extended family. Normally, the family lives together, pools its resources and works together and produces offspring. At least two of the adult members may be engaged in a sexual relationship in accordance with what the norms are for the particular society. Genetically, a family is a group of people affiliated by consanguinity, affinity or co-residence. There are several family typologies among which is the nuclear family which is the focus in this paper. The nuclear family generally comprises the husband, the wife and a very limited number of children. The husband is traditionally the male partner while the wife is the female partner with each of them performing different conjugal functions for the sustenance of the family.

\section{Conjugal Roles in the Family}

Conjugal roles refer to the domestic work and leisure activities which a husband and wife share in a marital relationship. Young and Willmott (1975) have identified two main types of roles - the joint conjugal roles and the segregated conjugal role. In some family typologies, the conjugal roles, the marital roles of husband and wife are segregated. That is, there is a clear-cut division of labour between the spouses in the family. In most cases, the husband is relatively uninvolved with domestic chores and the general care of the children. In some families, like the symmetrical type, conjugal roles are not so clearly delineated. However, the wife still takes responsibility for housework and childcare while the husband concerns himself with "laundry, ironing of clothes and the washing of the cars and other unspecified minor responsibilities". In some cultures, beliefs about conjugal role segregation are rooted deeply in traditional folklore. Among Irish peasant farmers, the plough, the harrow, the mower, the scythe, the spade and the slasher are regarded as masculine instruments. The attitudes of the countryside forbid women's use of these implements. In the same way, it is ridicule for men who show interest in feminine matters. Also, in many African cultures men who show interest in things feminine are usually ridiculed and described as "woman-wrapper". It is generally regarded as a very serious sign of weakness for a husband to be associated with kitchen or household work such as washing up plates, cooking and general cleaning up. The same is true for making beds in readiness for sleep, helping with children especially the very young ones or even ironing clothes especially his wife's clothes.

The husband is regarded as the head of the home, as he holds the house together. The wellbeing and the general balance of the family depends on the head who is expected to take care of his family by providing food, shelter, clothing, security and even education for his children while his duties to his wife are to love and respect her, to protect and take care of her especially with respect to her health and comfort. The husband has the responsibility for income support and the wife for the home and family matters. In order to be able to play his role, the husband has to work, that is, a gainful employment in order to bring income into his family.

The wife who is the female partner in a marriage is expected to be a house keeper, hence her role is more domestic in nature. Aspects of her housework include preparing meals, cleaning the house, laundry and mending of children's clothing, interior decoration and minor house/kitchen repairs. Even one of the holy books called her a "help mate".

\section{The Husband Wife}

The husband wide concept is one of the fast moving currents of social change. It is a complete break from the stereotypical gender or marital role situations. It was Joel Roache, an English Professor in his "Confessions of A Househusband" who revealed that it was:

only after I had assumed the role of househusband and was myself caught in the trap of domesticity, did I realize that the reality behind those stereotypes is a function of the role, not the person (Roache, 1991: 391).

The husband wife, unlike the househusband who has been trapped in the very mundane and trivialities of domesticity is the woman married to a man but finds herself performing all the masculine roles which are usually the exclusive preserve of the husband. Very unusually, in a role reversal situation, she assumes the role of a bread winner, a provider and perhaps the "head", while the husband now assumes the role of Roache's "househusband". The husband wife has shed off the garb of housewife since she has a booming career from which she earns a comfortable living. Because she is a husband wife, she earns more than her husband, that is, her income is usually more than her husband even if he is gainfully employed.

Meanwhile the husband turns a househusband trapped in the domesticity of housework like cooking, cleaning and 
childcare. The home, otherwise a "prison" for women now turns a "prison" for the man in a very frustrating and castrating situation. Of sociological significance is the question of the social status of men who are turned househusbands. They probably have been turned house husbands by circumstances that are beyond their immediate control. So, several questions may to asked: Are they self actualized? Are they to blame for their situation? How much authority do they wield in their matrimonial homes in view of the patriarchal colour of our society. These issues become even more pertinent when we realize that in our current political dispensation in Nigeria, many Nigerian female political office holders have become husband wives in almost all state capitals and the federal capital in Abuja where they attend days and weeks long political meetings while their husbands are taking care of the home front. This situation is a serious threat to family stability.

\section{What conditions promote the "husband wife" phenomenon?}

In the last fifty years, the institution of marriage has undergone very significant changes to the extent that the traditional conjugal roles and husband/wife positions have altered very significantly with many women out-pacing the men in several areas where the men have traditionally held sway. Many women have overtaken their menfolk in both education and earning. These unequal gains have been facilitated by gender role reversals in both spousal characteristics and the socio-economic benefits of marriage. While many men have married women whose education and financial standing far outstrip theirs, the global wind of affirmative action and the emancipation which accompanied the activities of women movements worldwide have affected conjugal roles even in very patriarchal cultures including Nigeria. The recent unfortunate incident of husband abuse (Musa, 1999) at the University of llorin, Nigeria, where the husband of a female Professor, out of frustration resorted to suicide because of the action of the wife who was obviously playing the role of husband wife is very instructive.

In a recent survey by Fry and Cohn (2001) of the Pew Research Centre, the analysis of the demographic and economic trend data indicted that a large share of men in 2007, compared to their 1970 counterparts were married to women whose education and income exceed their (husband's) own while a large share of women are married to men with less education and income.

Fig. 1: The Rise of Wives, 1970 to 2007

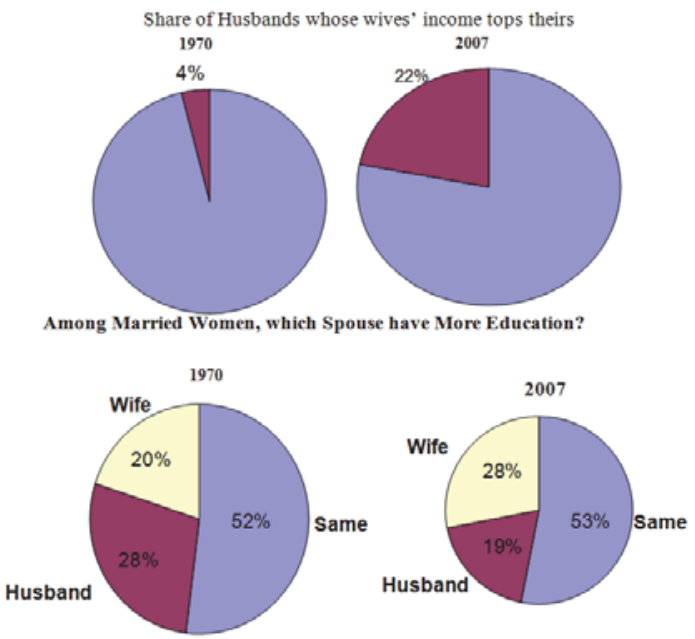

Note: Includes only native-born 30 to 44 years-olds.

Source: Decennial censuses and 2007 American Community Survey (ACS) Interpreted Public Use Micro Sample (IPUMS)

From the economic point of view, these trends have contributed to conjugal/gender role reversal in the gains from marriage. In the past, when relatively few wives were engaged in paid employment, marriage enhanced the socio- 
economic status of women more than men. Musa (1999) had observed this trend in the empowerment of women by the hierarchy of military officers both in the army and even when they manourver their way into political governance through coup d'etats. In recent times however the economic gains associated with marriage have been greater for men than for women.

\section{Recent trends in gender role reversal}

The Fry and Cohn (2001) report has also examined how changes at the nexus of marriage, income and education have played out among American men and women aged 30-44 - a stage of life when adults are supposed to have completed their education, get employed and settled down in marriage. Americans in this age bracket are the first such cohort in American history to include more women than men in college degree. For example in 1920, records show that $28 \%$ of wives in this age bracket had husbands who were better educated than they were, out numbering the $20 \%$ whose husbands had less education. By 2007 however, these patterns had reversed drastically. About 19\% of wives now had husbands who had more education as against $28 \%$ whose husbands had less education. In the remaining percentage about half, that is 50\% of the couples in 1970 and 2007 had similar educational levels. Similarly, only about $40 \%$ of husbands were married to women who were capable of bringing in more income than they did in 1990. This percentage rose to $22 \%$ in 2007. The demographic characteristics of husbands and wives have continued to oscillate. Women's earnings have grown $44 \%$ from 1970 to 2007, compared to the 6\% growth for men's earning.

The national economic downturn is reinforcing these gender reversal trends because it has negatively affected the employment of men more than that of the women. Males have accounted for about $72 \%$ of the 2008 decline in employment among prime - working - age individuals (The U.S.B.L.S. 2009).

Fig. 2: 1970-2007 American College Graduates

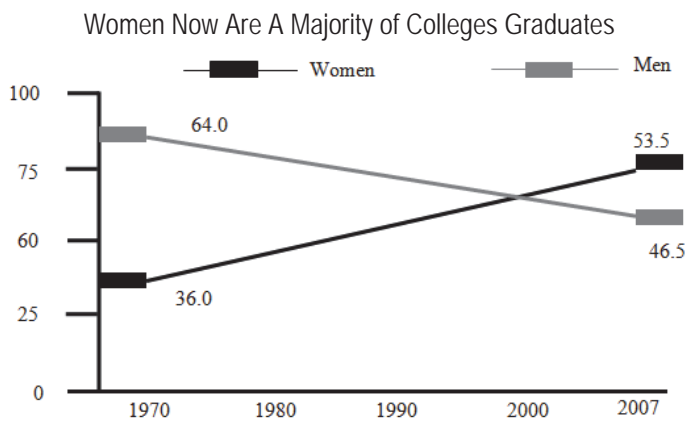

Note:Includes only native-born 30 to 44 years-olds.

Source: Decennial censuses and 2007 American Community Survey (ACS) Interpreted Public Use Micro Samples (IPUMS)

Educational attainment plays an important role in income. The higher the educational level of wives the more their income rises because they have a better chance of getting employment than their husbands who have no educational qualification. Therefore, for the home to keep afloat, a wife with a thriving job who brings in the bulk of the finance in the home can assume the role of the husband wife.

Another recent trend which has promoted the phenomenon of husband wife is the drive for a woman to marry a man she is much more educated than or that she earns more money than. This generally happens due to societal or even parental pressure on women who are crossing the thirty year bar to get married. In Nigeria, as in many other African cultures, the society expects that by age twenty or twenty five, a woman should have been married and even started rearing her biological children. The pressure may be so serious that in order to escape from such pressure she may just concentrate on acquiring a series of academic certificates and degrees and before long, she has out-priced herself from the very eligible bachelors most of whom may just be first degree holders or even just graduates of the National Certificate in Education (NCE). When she finally succumbs to the pressure to get married, the men who are available for marriage are either jobless educated men or even men who are in very menial jobs whose remuneration 
may not be able to sustain a marriage. There are also some men - the "money bags" who may not be able succumb to the indignitories of a househusband. Now it becomes pertinent to ask what factors can make a man succumb to the drudgery of a househusband?

Conditions which engender househusband: A number of studies which were carried out in the late 70 s and early 1980s indicated that a major condition which is predisposing to househusband is economic incapacity on the part of the menfolk. When a man is economically incapacitated as a result of unemployment and the wife is gainfully employed with a good take-home pay package, then a good ground is prepared for the husband to be a househusband. Lutwin and Siperstein (1985) had also described househusbands as husbands who are actively engaged in the domestic activities which are traditionally the exclusive preserve of wives. Such husbands are responsible primarily for the care of children and the home while their wives are the wage earners. The results of their research showed that while some husbands found themselves in this poison as result of job loss, some others were simply accidental.

One other factor which may have promoted the emergence of the phenomenon is social change. All over the world, social changes have swept over the continents as a result of the opening up of more opportunities for women and other less privileged segments of the society through the provision of education. Furthermore, industrialization has erased the once conventional idea that the wife's place is in the home as a home-keeper. Women have considerably liberated themselves in all respects to the extent that they now engage in all socio-economic activities which were ordinarily considered the exclusive preserve of men. What could be more revealing in this new trend than the recent Nigerian Television Authority (NTA) feature on a very successful female motor mechanic somewhere in Lagos, Nigeria. With many more women occupying very lucrative positions in the economy, the role of both husband and wife are increasingly becoming more diffuse than ever before. More enlightenment and education are also balancing and bridging the earstwhile stereotypical gender role gaps between husbands and wives.

\section{Educational implications of the "husband wife" phenomenon}

All education takes its root from the home. The home where the wife exercises the paraphernalia of authority including economic, social and moral is ordinarily not the ideal. That the situation has been described as a reversal of role means that the opposite of the reverse is the norm. Children learn through imitation. Parents who find themselves in this role reversal situation should endeavour not to over dramatize it such that the patriarchal authority structure such as the "father-figure" is not unnecessarily obviated. Both boys and girls in the family should be exposed to equal educational opportunity including the career choice.

Remedial, adult and continuing education programmes should be expanded in our educational provisions such that those adults who missed out earlier in life would have the opportunity to remediate their shortcoming through some remedial education programme. Vocational oriented educational programmes should also be encouraged so that products of the educational system could be self employed through some entrepreneurial activities.

\section{Conclusion}

The phenomenon of "husband wife" is real and it is here with us. Many wives have found themselves playing the role of the husband in terms of the provision of the essentials for the sustenance of the family. Families should therefore begin to be more realistic in their approach to marital issues. The concept and status of the institution of marriage are increasingly challenged by the wave of sweeping social changes. With increasing access to the socio-economic benefits of western education, the traditional conjugal roles of both the husband and wife are merging to the extent that the stereotyped gender distinctions are fast disappearing. The socio-economic realities of today have made it incumbent on both husband and wife to be deeply involved almost on equal basis in the running and maintenance of the home.

The payment of children's school fees and other school requirements and the general maintenance of the home all require a considerable amount of money. Families which have been established on the firm foundation of love should normally not experience unusual problems with respect to the sharing of responsibilities. There is therefore the need to reexamine the moral basis for the institution of marriage. When this is done, the "husband wife" situation in which a wife completely takes over the role of her husband in an unhealthy and almost castrating manner will not arise. In fact, the services of a house help (paid or free from a relation of the family) can mitigate for the husband the inherent husband abuse (Musa, 1999) associated with the "husband wife" situation. 


\section{References}

Chester, R. (1985) "The rise of the neo-conventional family". New Society (9, May, 1985).

Delphy, C. (1984) Close to Home. London: Hutchinson.

Fry, R. and Cohn, D. (2001) "The rise of wives" in New Economics of Marriage. Pew Research Centre.

Lutwia, D. and Sipenstein, G. (1985) "Male primary caregivers and domestic labour in Journal of Family. (48: 324-332). Univ of Queensland Press.

Musa, C.N. (1997) "The role of the Armed Forces in the empowerment of women in Nigeria" in The Counsellor: A Journal of the Counselling Assoc of Nigeria. Vol. 15, No. 1, pp. 154-160.

Musa, C.N. (1999) "Husband Abuse and its implications for family stability" in Knowledge Review: A Journal of the National Association for the Advancement of Knowledge (NAFAK). Vol. 1, No. 3, pp 01-05.

Roache, J. (1991) "The confessions of a househusband" in Down to earth Society: Introductory Readings. James Henslin, (ed). New York. The Free Press.

Radin, P. (1994) "Does it impact father's involvement with their children. www.fathersalwaysmatter.com/newslet...

Secombe, M. (1975) "Domestic Labour: Reply to critics" in New Left Review (Nov. -Dec).

Young, M. and Willmott, P. (1975) The Symmetrical Family. Harmondsworth, Penguin. 